\title{
Black African Scholars in European Academia before 1800
}

\author{
David de la Croix
}

IRES/LIDAM, UCLouvain

\section{INTRODUCTION}

How many members of European Universities and Academies originated from Sub-Saharan Africa during the Early Modern Period? Most people would say zero, and this is what I would have said a few years ago as well. Since I started collecting data on scholars and literati at European Universities and Academies, I had to revise my prior. Among 46,363 persons in my Repertorium today, there are three Black African scholars. This gives thus a lower bound on the exact number. Figure 1 is a plot of the places of birth of the Black African scholars. Let us give a short biography of these persons and conclude with some thoughts.

\section{Black African Scholars}

Juan de Sessa (Cabra (Spain) c.1518 -- Granada c.1596) Juan de Sessa was the son of a Black woman from Ethiopia, who was a slave of the Duke of Sessa in Spain. He was educated alongside his owner's son, benefitting from the education given to the young duke by participating in his lessons. Later, accompanying the young duke to the University of Granada (founded 1531), Juan de Sessa managed to follow the classes too, although not without difficulties, as he was not allowed to enter the classrooms, and had to listen from outside. Surprised by his achievements, the Dukes of Sessa allowed him to continue his career in letters at the University of Granada. He was known by the nickname Latino. In 1556, he received the Chair of Grammar and Latin language and held that post for 20 years. He translated both Latin and Greek classics and published several volumes of poems. In one of his poems, he searched to establish the dignity of all Black Africans, relating them to biblical Ethiopia and refusing the idea of natural slavery. He imagined white people subordinated in Ethiopia (a reversed irony) and exalted Blackness in the final verses (Fra-Molinero 2005, Fiérrez 2020).

Anton Wilhlem Amo (Axim (Ghana) 1703 - Shama (Ghana) 1753) Amo was born around 1703 near the town of Axim in present-day Ghana. He grew up in Amsterdam, after being given as a "present" to a wealthy family, who provided him with an education. He went to university in Helmstedt, then in Halle. Amo completed his first dissertation at the University of Halle on a legal and historical argument against European slavery Dissertatio Inauguralis de fure Maurorum in Europa. He gained his doctorate in philosophy at the University of Wittenberg in 1734; his thesis (De Humanae Mentis Apatheia Seu Sensionis Ac Facultatis Sentiendi In Mente Humana Absentia Et Earum In Corpore Nostro Organico Ac Vivo Praesentia translated as "On the Absence of Sensation in the Human Mind and its Presence in our Organic and Living Body") argued against mind-body dualism, in favour of a materialist account of the perceptions and feelings. Amo published works across a variety of disciplines from philosophy to psychology and established himself as a renowned Enlightenment thinker. He went on to teach at the University of Jena. After the death of his protector, the Duke of Brunswick, and perhaps 


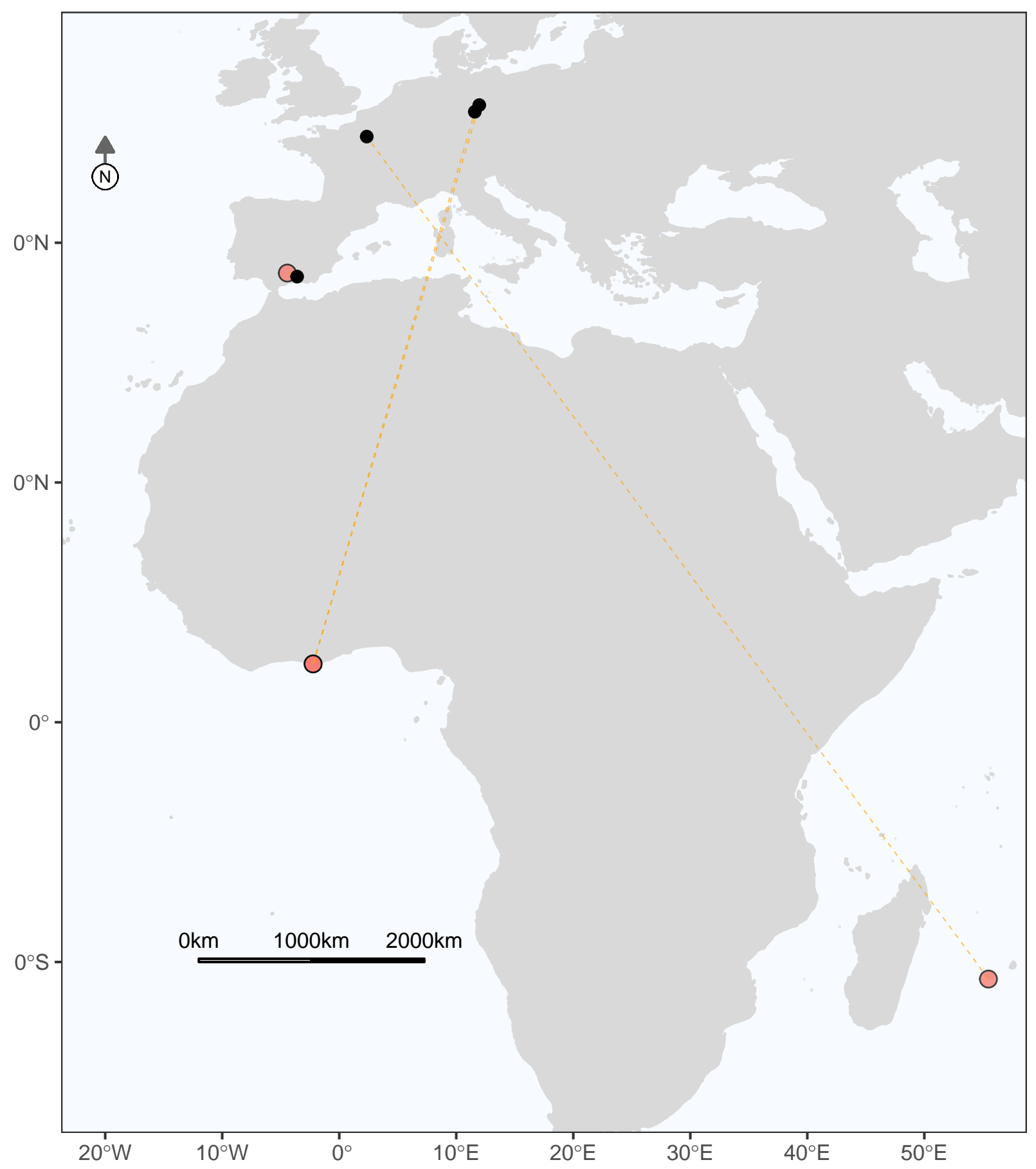

Figure 1: Place of birth of the Black African scholars 
subject to racism and opposition to his militancy in favor of abolitionism, he sailed back to present-day Ghana, where he remained for the rest of his life (Grégoire 1808, Google 2020).

Jean-Baptiste Lislet Geoffroy (Saint-Pierre 1755 - Port-Louis 1836) Lislet Geoffroy was the illegitimate son of Jean-Baptiste Geoffroy, a French engineer working in Mauritius (then called Île de France) and a freed black slave from Guinea. He was a naval officer in the body of military engineers, in charge of cartography. In 1786, he was elected to the Royal Academy of Sciences (Paris) as a corresponding member. The Academy was abolished in 1793, and replaced by an Insitute of Sciences and Arts, in which, according to Grégoire (1808), Lislet Geoffroy was the only member of the Royal Academy not to be renewed, probably because of his color. Lislet Geoffroy published magnificent maps of several islands in the Indian Ocean, and works in geology on the volcanic nature of Mauritius (Anonymous 1837).

\section{CONCLUSION}

Does the presence of these Black Africans in European Academia mean that there was less discrimination in the past than we expect? Of course not. Although the Martin Luther University of Halle-Wittenberg tries today to highlight the presence of Amo in Halle, for example by erecting a statue and granting a prize in his honor, it is easily verifiable in the online Catalogus Professorum Halensis that he did not get access to the full professorship at that time. He was probably giving lessons as a private scholar. The situation in Jena seems to be similar. It might be the case that he gave some lectures, but he was not a professor and has no entry in the authoritative source for Jena (Günther 1858). But the presence of these Black African scholars shows that behind aggregate numbers, a share of $0.0054 \%$ of black professors, there are individual stories that showed some unconventional paths.

\section{ACKNOWLEDGMENTS}

This project has received funding from the European Research Council (ERC) under the European Union's Horizon 2020 research and innovation programme, under grant agreement No 883033 "Did elite human capital trigger the rise of the West? Insights from a new database of European scholars."

Thanks to Alice Fabre for showing me the article published in Le Monde on February 1, "Anton Wilhelm Amo, philosophe noir des Lumières". This article is not correct as it claims Amo was the first Black African to teach at a university in Europe, while I showed here the case of Juan de Sessa, who preceded Amo by two centuries. I also thank Robert Stelter for highlighting the importance of Amo today for the University of Halle-Wittenberg.

First version February 24, 2021.

\section{REFERENCES}

Anonymous. 1837. "Biographical Notice of the Mulatto M. Lislet-Geoffroy, Correspondent of the Academy of Sciences for the Section of Geography and Navigation." The Edinburgh New Philosophical fournal 22:70-77.

Fiérrez, Eduardo Soler. 2020. "Juan Latino, la biografía del esclavo catedrático de Granada." Course on "Cultura y Pensamiento de los Pueblos Negros", Universidad Complutense Madrid, https: //culturaypensamientodelospueblosnegros.com/.

Fra-Molinero, Baltasar. 2005. "Juan Latino and his racial difference." Chapter 15 of Black Africans in Renaissance Europe, edited by Thomas Foster Earle and Kate Lowe. Cambridge: Cambridge University Press.

Google. 2020. "Google Celebrates Ghanaian Philosopher Anton Wilhelm Amo with a Doodle/art." https://www.google.com/doodles/celebrating-anton-wilhelm-amo. 
Grégoire, Henri. 1808. De la littérature des nègres, ou recherches sur leurs facultés intellectuelles, leurs qualités morales er leur littérature; suivies de notices sur la vie et les ouvrages des nègres qui se sont distingués dans les sciences, les lettres et les arts. Paris: Maradan.

Günther, Johannes. 1858. Lebensskizzen der Professoren der Universität fena seit 1558 bis 1858. Jena: Friedrich Mauke. 